\title{
Policymaking in a Multiethnic State, the Legal Changes, Practice of Macedonia
}

\author{
Besa Kadriu \\ PhD Cand., South East European University \\ Blerta Arifi \\ $\mathrm{PhD}$ Cand., South East European University
}

\begin{abstract}
In contemporary terms and conditions, in addition to economic and social factors, political processes are one of the basic components of the proper functioning of a multi-ethnic state. Examples of proper practices of multiethnic states which operate in conformity with international standards, within the EU structures abound. This is in a group of countries which have previously significantly overcome the problems of transition and reform of the political system and have managed to establish standard which are inaccessible and levels of genuine democracy. The paper has aspirations to take into consideration the comparative aspects which can serve as a good example of the changes and development of the country towards Euro-Atlantic structures. That it happens with Western Balkan countries. The situation becomes even more difficult, especially in those cases where states and societies of the population is heterogeneous structure; Case of Macedonia, being convinced that has to do with a diverse population, the country still today fails to cross the barriers of the past from the old system. Institutions and decision-making bodies, now more than ever need to change policymaking process, prevention of discrimination and compliance values of the political, economic and social conformity with European standards. ${ }^{1}$
\end{abstract}

Keywords: Policymaking, law, multi-ethnicity, reform institutions, bodies.

\section{Introduction}

"The practice has shown that in most cases the parts of the Western Balkan, countries that comprise it, today are still under the influence of an experience that has served system of the past." B.K.

This sentence verify nowadays experiences of Macedonia as a country with one notable symbolic existence as an independent state were there needs more tendencies and work to achieve up to minimum standards of a position at least for this phase should possess as an independent state.

Period after the 2001 conflict was not an easy process but also as well as extended as it can and as much as more there are seeing consequences every day more in shoulders of citizens in Macedonia.

First impression that comes in consideration, if we look forward at the current political situation in Macedonia with the latest technology known as "Political drone" will detect some problems that will make us to understand the real situation and our experience, does not differ much from turmoil that have gripped international politics today. It differs in the way of its manifestation and the genesis of the problem which can be another plan. If we pretend to do a study of a deeper nature of this issue then, we see that while the political actors in the whole world would try to find solutions of problems; Macedonia and political situation even more stretched its political actors. The difference is noted at the outset. Although, the European

\footnotetext{
${ }^{1}$ For more details about the EU establishment and case of Macedonia till the status candidate, there are more details that confirm the notes and important dates during this process; http://ec.europa.eu/enlargement/countries/detailed-country-

information/fyrom/index_en.htm
} 
continent - Western Balkans occupies a space approximately, 550,000, per square meter, the latter's problems in every part are separate model. What happens with political experience in Macedonia? In international political opinion experience as ours much more is influenced from domestic circumstances; there is no doubt understood that the consequences of a one-party system felt in nowadays conditions. Although since political pluralism, Macedonia has been occasionally ratification actor and approval of many international acts and those in local dimension and size of other lower, again we are witnessing flagrant violation of these rights by the own state institutions.

Multiethnic character of society within which is part Macedonia's experience as a state in the Balkan, however that was the impression that the international community, from the conflict in 2001 reduced tensions with the signing of a joint political entities bilateral at that time, the current situation proves otherwise. ${ }^{1}$

Not only does it solve the problem of inequality between ethnic groups that make up Macedonia, but despite that, the situation is even tenser. Today, no citizen or in other words few people whom you do not staged a particular case where the protagonist in the role of perpetrator always comes Albanian or other case or scenario mounted, the outcome of which is not known and never finished in Albanians favor.

From the viewpoint of an ordinary citizen, every one of us in situations like this and the way reasoning showed that, of course, that the charges directed by state power, this device provide violence appeared increasingly driven by Albanians unilaterally. It is now clear, whenever that come are honored powers or governments, charges for their failures and failures, eyes always directed towards Albanians. Whenever problems not generate crisis and find a solution, open armed conflict, as was the case last time, in the Kumanovo, indicating the crisis who are factor that ask only ones who through weapons want to realize the solution of the problems and the goals of society. Being the leader of policies such nationalist political parties' Macedonian doing, they forged that generate the political chaos not only to the political parties of the Albanians but also to themselves and as a result the situation gets out of control even greater proportions involving again the international political factor.

Experiences such political processes already convincingly make us clear that citizens feel trampled, governed in the form of chaotic model that exercised violence and tyranny, abuses by institutions and legitimacy of the policy, which is what we understood from interceptions last; They are one more argument to believe that this regime does not cause anything other than the destruction of the fundamental values of democracy and the collapse of a system that is in exoneration. Before situations and experiences of these are living proof of the violation of human dignity, many of the political figures of the time and other stakeholders as members of the National Liberation Army of 2001, government at all costs tried to overshadowed image of these structures created the experience of the Albanian political bloc in order to achieve the aspirations which were contrary to every aspect and with the concept of good governance. In this regard, they used unfair mounted who prove that we who urge problems are the ones who do not have representatives devoted political and many accusations without basis which is a concept and not very enviable international factor.

Evidence suggests that this political un-standardized format in Macedonia experience for a system like this that speaks of democracy but the facts lead to totalitarianism, that political entities that make up the multi-ethnicity and ethnicities in Macedonia who participate in power but do not imply political processes, political actors who sign the Stabilization and Association Agreement, but generated largely instability; guaranteeing the rights to use the language; education and the use of symbols of Albanians but never respected. It remains to be mentioned that the formal representation, just as the number but not increase effective impact role key decision-making by ethnic Albanians ... it seems elusive for an opinion wider, but this scene speaks clearly for a reality as elusive as the paradoxical to; based on the reality of the time in which we live. Typically, therefore I will also continue while image of people who are considered to have an impact on political life tends to fade, giving space more those whom you serve tendencies political protect the image of a political servile which leads towards inculcating interest which tried to create for years, be a multiethnic society that would worthily represented the country at the relevant institutions, thus giving more space and peaceful way of conflict resolution that were in defense of common interests.

We, as citizens, members of the state feel themselves without influence not only in the structures of the State but also by a significant number of people who remain faithful to this structure that governs which day by day undermines our families,

1 http://www.ucd.ie/ibis/filestore/Ohrid\%20Framework\%20Agreement.pdf 
evoke fear mass wide, not undertake any decision to improve economic status, political and social society in general. Misuse of counterfeiters have become part of the experience of certain services of the state that There is no doubt that this thing goes in favor tendencies criminal generated by state services of that country and more using people from among Albanians only to be in favor of a destructive policy that harms our image as an important factor in political life and decisionmaking process.

These situations and discontent will last as long as the structures of the Albanian political bloc will this policy to actual premier and while stay sitting under power chairs. Where there is given an opening voices of citizens should not be said that there is democracy ... where government imposed by force, it lacks legitimacy ... where religious principles used for certain aspects of the ideas of manipulation of the masses, there is no morality ... where socially , political deviated hardly find the balance ... now s' remains nothing, except that in this labyrinth culprits end there you have the land, to hope that criminals will get what they deserve, because before the fact bow angels.

The international community has played a very constructive role in easing inter-ethnic relations and creating a mild climate between the two majority ethnic groups that make up Macedonia.

In this case, the Ohrid Agreement was one of the acts created with the mediation of the United States of America and European policy actors.

As a result, even today, after almost 15 years, cannot be concluded with certainty to complement this country has fulfilled obligations not only to the international community, but first even to its citizens.

This disappointment can verify through consecutive facts argued by periodic reports addressed to Macedonia, as a candidate country by the European Commission.

Notice given principally in the area of justice, failure to state of law, public administration overwhelmed, at a time when the European Union requires sitting of employees in administration to be limited, domination economy darker, market dysfunctional then remarks are focused in three dimensions Copenhagen criteria addressed to the Western Balkan countries which are closely related to the eligibility criteria, political and economic.

All three of these conditions, in the case of Macedonia still today are a realistic suspicion!?

In the field of cooperation from the international politics of defense and security, it should be noted that there were some training in cooperation with the OSCE, but after that, there are a number of elements which come and create obligatory for countries that are strongly in process development.

The training activities of OSCE are not only confined with basic police training. Additionally, professional training programs, requested and approved by the role and they are an integral part of the PDU's exit strategy:

- Instructor development training - a comprehensive training programs designed for national police instructors.

- Reform training - programs for all existing uniformed officers to ensure that they receive training consistent with what was delivered to the newly-graduated police cadets. Police officers receive additional training in human rights, policing in a democracy, gender awareness, trafficking in human beings, domestic violence, officer safety and drug identification.

- Specialized training programs - specialized and advanced training programs for selected officers are provided in topic areas such as: trafficking in human beings, road safety, border, human rights and democratic policing and election security.

- In-service training programs - a forum seeking to prepare the recently graduated, probationary police to successfully pass the State Examination and receive executive authority. ${ }^{1}$

\footnotetext{
1 Introducing Multi-Ethnic Policing in Macedonia1: The Role of the OSCE , Ali DiKiCi

Web Page, http://www.osce.org/skopje/pdu, (accessed 09 April 2004).article

Uluslararası Hukuk ve Politika Cilt 3,No:10 ss.129-146, 2007@
} 
With the help of the OSCE, the interior ministry has assumed full responsibility for the border police and in 2005 the newly formed Border Police completed its transfer from the Ministry of Defense to the Ministry of Interior. This critical step means that the entire territory is under the administration of the police, as in other European countries. The military no longer has security obligations within the country. In 2006 the border police established regional training coordinators and the Mission began training internal trainers who will assume the task of further developing their colleagues' policing skills. ${ }^{1}$

\section{Recomenadations}

[1] And the most important, building bridges of peace among people with different religions and without prejudices society.

[2] Arranging a mild climate between ethnic groups, Albanian / Macedonian or proper function of a multi-ethnic society;

[3] Based on those wrong experiences which are non-sense for one state as Macedonia is, in process of integration, now state, it will be faced with new elections on December 2016.

[4] Creation of proper policies of social welfare;

[5] Effective public policy on defense and security in the country, if it is very necessary, especially in countries as part of the Western Balkans where post-conflict, the need for public safety is increasingly necessary.

[6] Full transparency of institutions in the country;

[7] Functioning of a democratic system that would function in the general interest of citizens;

[8] Hopefully, in this contest, state will choose the best way to attach as a strategic program for one better future for their citizens without any ethnic background.

[9] Political stability, economic and social development in general.

[10] Proper functioning of the legal system, which currently has a bitter experience of distortion of law;

[11] Respect for fundamental democratic values;

[12] The creation of conditions in the country for accession to the Euro-Atlantic structures;

[13] These are some of the basic elements which in the case of Macedonia have a handicap, but have a willingness genuine stakeholder relevant to policy to receive the appropriate measures in cooperation with the international community to give a permanent contribution to rebuild genuine values of states developing, where it is part of Macedonia.

${ }^{1}$ OSCE Annual Report 2006, p. 46 